\title{
ANALISIS YURIDIS DASAR PERTIMBANGAN HAKIM DALAM MENJATUHKAN PUTUSAN TERHADAP PELAKU TINDAK PIDANA PEMALSUAN SURAT BERDASARKAN PASAL 263 KUHP (Putusan 876/Pid.B/2019/PN Rap )
}

\author{
Muhammad Rafi'i Abdillah \\ Program Studi Hukum, Universitas Labuhanbatu, Sumatera Utara
}

\begin{abstract}
Falsification of signatures or stamps / stamps is one of the forms of letter forgery and the use of fake letters in question is someone who deliberately uses a letter that he knows is fake. Using a forged or falsified letter is one of the criminal acts regulated in Chapter XII Book II Article 263 paragraph 2 of the Criminal Code (KUHP). Formulation of Article 263 of the Criminal Code.

The approach method used in this study is a normative method supported by empirical methods. In this article, it is emphasized that in its use, you must really know that the letter used is fake and can cause harm. With the existence of legal provisions regulating these crimes, according to the function of the law as a means of social control and punishment as a repressive effort to tackle crimes.

Keywords: Letter forgery, Judge's Consideration, Article 263 of the Criminal Code

ABSTRAK

Pemalsuan tanda tangan ataupun cap/stempel merupakan salah satu diantara bentuk pemalsuan surat dan Penggunaan surat palsu yang dimaksud ialah seseorang yang dengan sengaja menggunakan surat yang diketahuinya adalah palsu. Menggunakan surat palsu atau yang dipalsukan merupakan salah satu tindak pidana yang telah diatur dalam Bab XII Buku II pasal 263 ayat 2 Kitab Undang Undang Hukum Pidana (KUHP). Rumusan Pasal 263 KUHP.

Metode pendekatan yang digunakan pada penelitian ini adalah metode normatif yang didukung oleh metode empiris. Pada pasal tersebut ditekankan bahwa dalam penggunaannya harus benar-benar mengetahui bahwa surat yang di gunakan itu adalah palsu dan dapat mendatangkan kerugian. Dengan adanya ketentuan hukum yang mengatur kejahatan tersebut,maka sesuai dengan fungsinya hukum sebagai alat pengendali sosial dan pemidanaan sebagai suatu upaya represif untuk menanggulangi kejahatan..
\end{abstract}

Kata kunci : Pemalsuan Surat, Pertimbangan Hakim, Pasal 263 KUHP

\section{PENDAHULUAN}

\subsection{Latarbelakang}

Kebutuhan hidup dapat dipengaruhi oleh berbagai aspek-aspek sosial, lingkungan, dan aspek lainnya khususnya pada aspek ekonomi sehingga modus pelaku tindak kejahatan menyasar objek yang linear dengan aspekaspek yangmempengaruhinya.
Sesuai dengan ketentuan Undang Undang Dasar NKRI tahun 1945 bahwa:"Negara Kesatuan Republik Indonesia Merupakan Negara Hukum”. Ketentuan pasal tersebut merupakan landasan konstitusional bahwa Indonesia adalah negara yang berdasarkan atas hukum, hukum ditempatkan sebagai satu- satunya aturan main dalam 
kehidupan bermasyarakat, berbangsa dan bernegara (supremacy of law). Hukum tersebut diyakini sebagai alat untuk memberikan kesebandingan dan kepastian dalam pergaulan hidup guna mencapai tujuan negara Republik Indonesia yaitu untuk mewujudkan masyarakat adil dan makmur berdasarkan Pancasila.

Kita ketahui bahwa hukum ikut berkembang seiring dengan permasalahan yang terjadi dimasyarakat. Meskipun hukum mengikuti perkembangan kehidupan masyarakat tetapi melihat dewasa ini tidak dapat menjadi tolak ukur akan minimalnya kejahatan ,melihat kehidupan di masyarakat cukup banyak permasalahan yang timbul akibat kejahatan baik itu yang mendatangkan kerugian pada individu, masyarakat maupun negara.Sebagai salah satu bentuk kejahatan yang cukup banyak dilakukan oleh masyarakat adalah kejahatan pemalsuan atau Tindak Pidana Pemalsuan.

Menurut P.A.F dan Theo Lamintang (2016.), dari sejarahnya dapat diketahui bahwa pengaturan masalah tindak pidana pemalsuan di dalam Code Penal ternyata juga mendapat pengaruh dari pengaturan masalah tindak pidana yang sama di dalam Hukum Romawi. Menurut Hukum Romawi, yang dipandang sebagai de eigenlijke falsum atau sebagai tindak pidana pemalsuan yang sebenarnya ialah pemalsuan surat-surat berharga dan pemalsuan mata uang, dan baru kemudian telah ditambah dengan sejumlah tindak pidana yang sebenarnya tidak dapat dipandang sebagai pemalsuan-pemalsuan, sehingga tindak pidana tersebut di dalam doktrin juga disebut quasi falsum atau pemalsuan yang sifatnya semu.

Desi Wulandari berpendapat bahwa "kejahatan pemalsuan sebagai salah satu tingkah laku yang menyimpang dan bertentangan dengan hukum serta merugikan masyarakat, saat ini telah berkembang pesat baik modus operandi maupun pelakunya.

Pemalsuan sendiri diatur dalam BAB XII Buku II KUHP,buku tersebut mencantumkam bahwa yang termasuk pemalsuan hanyalah berupa tulisan-tulisan saja,termasuk di dalamnya pemalsuan surat yang diatur dalam Pasal 263 KUHPidana s/d pasal 276 KUHPidana. Tindak pidana yang sering terjadi adalah berkaitan dengan Pasal 263 KUHP (membuat surat palsu atau memalsukan surat), dan Pasal 264 (memalsukan akta-akta otentik dan Pasal 266 KUHP menyuruh memasukkan keterangan palsu ke dalam suatu akta otentik).

Perbuatan membuat surat palsu adalah perbuatan membuat sebuah surat yang sebelumnya tidak ada/belum ada,yang sebagian atau seluruh isinya palsu. Sementara perbuatan memalsukan adalah segala wujud perbuatan apapun yang ditujukan pada sebuah surat yang sudah ada, dengan cara menghapus, mengubah atau mengganti salah satu isinya surat sehingga berbeda dengan surat semula. Surat ini disebut dengan surat yang dipalsukan. Kejahatan kedua ini merupakan perbuatan yang dianggap sebagai kejahatan yang 
bertentangan kepentingan pribadi maupun kepentingan umum.

Pemalsuan tanda tangan ataupun cap/stempel merupakan salah satu diantara bentuk pemalsuan surat dan Penggunaan surat palsu yang dimaksud ialah seseorang yang dengan sengaja menggunakan surat yang diketahuinya adalah palsu. Menggunakan surat palsu atau yang dipalsukan merupakan salah satu tindak pidana yang telah diatur dalam Bab XII Buku II pasal 263 ayat 2 Kitab Undang Undang Hukum Pidana (KUHP). Rumusan Pasal 263 KUHP, sebagai berikut :

(1) Barang siapa membuat surat palsu atau memalsukan surat, yang dapat menerbitkan suatu hak, sesuatu perjanjian (kewajiban) atau sesuatu pembebasan utang, atau yang boleh dipergunakan sebagai keterangan bagi sesuatu perbuatan, dengan maksud akan menggunakan atau menyuruh orang lain menggunakan surat - surat itu seolah olah surat itu asli dan tidak dipalsukan, maka kalau mempergunakannya dapat mendatangkan sesuatu kerugian dihukum karena pemalsuan surat, dengan hukuman penjara selama - lamanya enam tahun.

(2) Dengan hukuman serupa itu juga dihukum, barang siapa dengan sengaja menggunakan surat palsu atau yang dipalsukan itu seolah-olah surat itu asli dan tidak dipalsukan, kalau hal mempergunakan dapat mendatangkan sesuatu kerugian.
Pada pasal tersebut ditekankan bahwa dalam penggunaannya harus benar-benar mengetahui bahwa surat yang di gunakan itu adalah palsu dan dapat mendatangkan kerugian. Dengan adanya ketentuan hukum yang mengatur kejahatan tersebut,maka sesuai dengan fungsinya hukum sebagai alat pengendali sosial dan pemidanaan sebagai suatu upaya represif untuk menanggulangi kejahatan.

\subsection{PerumusanMasalah}

Berdasarkan latar belakang masalah dapat diambil rumusan masalah sebagai bentuk pembatasan terhadap pembahasan. Adapun rumusan masalah yaitu Bagaimana pertimbangan hukum majelis hakim dalam penjatuhan putusan terhadap pelaku tindak pidana pemalsuan surat berdasarkan pasal 263 ayat 1 KUHP (studi Putusan 876/Pid.B/2019/PN Rap)?.

\section{METODE PENELITIAN}

\subsection{Bahan dan Data Penelitian}

1. Data Primer, yaitu data yang diperoleh dari wawancara langsung, dalam hal ini berupa data yang terhimpun dari pihak yang terkait.

2. Data sekunder, yaitu data yang diperoleh oleh dari kajian pustka, berupa buku buku, peraturan perundang - undangan, seta literatur lainnya.

3. Bahan hukum tersier, yaitu bahan hukum yang memberikan petunjuk maupun penjelasan atas bahan hukum primer dan sekunder, berupa kamus dan 
ensiklopedia. Selain itu juga buku mengenai metode penelitian dan penulisan hukum untuk memberikan penjelasan mengenai teknik penulisan(Soerjono Soekanto, 1986).

\subsection{Cara Kerja Penelitian}

Metode penelitian ini menggunakan jenis penelitian yuridis normatif dan yuridis empiris. Metode penelitian yuridis normatif adalah metode penelitian yang mengacu pada norma-norma hukum yang terdapat dalam perundang-undangan. Dalam penelitian yuridis normatif yang dipergunakan adalah merujuk pada sumber bahan hukum, yakni penelitian yang mengacu pada norma-norma hukum yang terdapat dalam berbagai perangkat hukum yang dapat digunakan untuk menganalisa permasalahan yang dibahas ${ }^{1}$, sedangkan yuridis empiris adalah suatu metode penelitian hukum yang berfungsi untuk melihat hukum dalam artian nyata dan meneliti bagaimana bekerjanya hukum di lingkungan masyarakat. Dikarenakan dalam penelitian ini meneliti orang dalam hubungan hidup di masyarakat artinya dengan cara wawancara kepada informan, maka metode penelitian hukum empiris dapat dikatakan sebagai penelitian hukum sosiologis.Cara-cara pengumpulan data sebagai berikut.

1. Penelitian kepustakaan (library research) Pengumpulan data pustaka diperoleh dari sebagai data yang berhubungan dengan hal-hal yang diteliti, berupa buku dan literatur-literatur yang berkaitan dengan penelitian. Disamping itu juga data yang diambil penulis ada yang berasal dari dokumen-dokumen penting maupun dari peraturan-peraturan perundang-undangan yang berlaku.

2. Penelitian lapangan (field research) Untuk mengumpulkan data penelitian lapangan Penulis menggunakan dua cara yaitu:

a. Wawancara, yaitu pengumpulan data dalam bentuk tanya-jawab yang dilakukan secara langsung kepada responden.

b. Studi dokumentasi yaitu mempelajari bahan-bahan hukum yang tersedia sejak dilakukan proses hokum dalam perkara ini yaitu mulai dari mempelajari dokumen pada tingkat penyidikan, penuntutan, dan pemeriksaan dimuka siding pengadilan.

\subsection{Analisis Data}

Data yang telah diperoleh dan dikumpulkan baik bahan hukum primer, bahan hokum sekunder maupun bahan hokum tersier maka data tersebut diolah terlebih dahulu, dianalisis secara kualitatif, selanjutnya disajikan dengan cara deskriptif yaitu dengan menjelaskan, menguraikan dan 
menggambarkan permasalahan beserta penyelesaiannya yang berkaitan erat dengan penulisan ini.

Dalam menganalis data berupa peraturan perundang-undangan maka akan dilakukan langkah-langkah sebagai berikut :

a. Inventarisasi aturan hukum yang terkait dengan fakta hukum

b. Klasifikasi aturan hukum dan buat sistematika pengaturannya

c. Deskripsikan konsistensi, kontradiksi pada aturan hukum

III. HASIL PENELITIAN DAN PEMBAHASAN

3.1 Alat Bukti Yang Dipergunakan Dalam Pembuktian

a. Keterangan Saksi dan Terdakwa Adapun keterangan saksi dan terdakwa sebagaimana termaksud dalam putusan adalah sebagai berikut:

1. Saksi Drs.Ch, dibawah sumpah pada pokoknya menerangkan sebagai berikut:

- Bahwa yang saksi mengetahui permasalahan atau kasus pemalsuan setelah saksi dipanggil oleh Penyidik Polda. Sumut;

- Bahwa kemudian saksi diperlihatkan mengenai surat tersebut didepan persidangan yaitu :

(1) Surat Keterangan No $593.3 / 198 / 1512 / 1989, \quad$ yang dikeluarkan oleh Kepala Desa Telaga Suka An. Thamrin Salak tanggal 16 Oktober1989 dan diketahui oleh Camat Panai Tengah An. Drs: Chairuddin;

(2) Surat Keterangan No $593.3 / 199 / 1512 / 1989$, yang dikeluarkan oleh Kepala Desa Telaga Suka An. Thamrin Salak tanggal 16 Oktober1989 dan diketahui oleh Camat Panai Tengah An. Drs. Chairuddin

(3) Surat Keterangan No 593.3/203/1512/1989, yang dikeluarkanoleh Kepala Desa Telaga Suka An. Thamrin Salak tanggal 16 Oktober 1989 dan diketahui oleh Camat Panai Tengah An. Dis. $\mathrm{Ch}$;

(4) Surat Keterangan No 593.3/204/1512/1989, yang dikeluarkan oleh Kepala Desa Telaga Suka An. Th Salak tanggal 16 Oktober1989 dan diketahui oleh Camat Panai Tengah An Drs. Ch

(5) Surat Keterangan No $593.3 / 200 / 1512 / 1989$. yang dikeluarkan oleh Kepala Desa Telaga Suka An, Th S tanggal 16 Oktober 1989 dan diketahui oleh Camat Panai 
Tengah An. Drs. Ch: Bahwa

saksi tidak mengetahui surat tersebut dan saksi juga tidak pernah menanda tangani surat itu saat saksi menjabat sebagai Camat Panai Tengah :Bahwa tanda tangan didalam surat itu bukan tanda tangan saksi karena saksi mengenal tanda tangan saksi sendiri

- Bahwa saksi diperlihatkan di persidangan mengenai surat Penyerahan Ganti Rugi atas nama Terdakwa Bahwa saksi tidak mengetahui surat-surat bermeterai 6000 tersebut diatas dan saksi tidak mengetahui siapa yang membuat surat tersebut;

- Bahwa yang bernama $\mathrm{Hj}$. Nega Hasibuan adalah mertua perempuan dari Terdakwa dan Baital adalah mertua laki-laki Terdakwa; Bahwa semua arsip surat tanah ada di Kantor Camat bukan di Desa, karena Camat sebagai PPAT, surat sebagai arsip dan semua surat yangdibuat oleh Kepala Desa terkait tanah wajib diketahui oleh Camat,

- Bahwa Desa Telaga Suka arah ke Tengah Kota dan Desa Cabang arah ke Pantai dan kedua Desa tersebut masuk dalam daerah Panai Tengah Labuhan Bilik;
- Bahwa sepengetahuan saksi materai 6000 belum Berlaku pada Januari-Februari 2000

- Bahwa saksi dan Terdakwa tidak pernah membuka kebun bersama sama di Panai Tengah;

- Bahwa saksi membenarkan barang di persidangan tersebut keterangan saksi tersebut. Terdakwa menyatakan keberatan karena Terdakwa dan saksi pernah bersama-sama membuka kebun di Panai Tengah;

2. Saksi MYS, dibawa sumpah pada pokoknya menerangkan sebagai berikut:

- Bahwa saksi adalah Kepala Desa Telaga Suka:

- Bahwa saksi mengetahui ada sengketa tanah antara Terdakwa dengan PT. Hijau Pryan Perdana (HPP) terkait adanya surat palsu:

- Bahwa lahan yang sengketa tersebut berada di Dusun VII Desa Telaga Suka Kecamatan Panai Tengah Kabupaten Labuhanbatu;

- Bahwa kemudian saksi diperlihatkan surat Keterangan tanah dipersengketakan

- Bahwa atas surat tersebut diatas saksi tidak mengetahuinya;

- Bahwa selanjutnya saksi diperlihatkan di persidangan mengenai surat Penyerahan 
Ganti Kerugian atas nama terdakwa.

- Bahwa saksi kenal dengan SN yang merupakan mantan Kepala Desa Telaga Suka; Bahwa saksi tidak kenal yang bernama $\mathrm{M}$. Nasir, Sofyan dan Muhyar karena bukan warga saksi;

- Bahwa saksi mengetahui Terdakwa ada memiliki lahan di Dusun VII Desa Telaga Suka Kecamatan Panai Tengah Kabupaten Labuhanbatu namun persisnya saksi tidak tahu; Bahwa Terdakwa ada membayar Pajak Bumi Bangunan untuk lahan seluas + 2 (dua) Ha selama saksi menjabat sebagai Kepala Desa namun saksi tidak mengetahui asal usul tanah tersebut;

- Bahwa di Kantor Desa sebelumnya tidak ada buku register tentang tanah;

- Terhadap keterangan saksi tersebut, Terdakwa menyatakan tidak keberatan;

3. Saksi SP, dibawah janji pada pokoknya menerangkan Bahwa saksi bekerja di PT. Hijau Pryan Perdana (HPP) menjabat sebagai Senior Manager:

- Bahwa PT. Hijau Pryan Perdana (HPP) ada mempunyai sebidang tanah di Desa Telaga Suka
Kecamatan Panai Tengah

Kabupaten Labuhanbatu

kemudian Terdakwa mengklaim dia sebagai pemilik tanah yang dikuasai oleh PT. Hijau Pryan Perdana (HPP) tersebu lalu Terdakwa mengajukan gugatan perdata di Pengadilan Negeri Rantauprapat yang mana Terdakwa selaku Penggugat dan PT. Hijau Pryan Perdana (HPP) sebagai Tergugat: Bahwa ada pun hasil putusan gugatan perdata pada Pengadilan Negeri Rantau Prapat adalah menerima dan mengabulkan gugatan Penggugat sesuai dengan Putusan Nomor 25/Pdt.G/2011/PN RAP tanggal 2 Agustus 2012 lalu Banding di Pengadilan Tinggi Medan dengan putusan menguatkan Putusan Pengadilan Negeri Rantau Prapat sesuai dengan Putusan Nomor 120/PDT/2013/PT MDN tanggal 27 Juni 2013 dan pada tingkat kasasi Mahkamah Agung dengan putusan menolak Kasasi sesuai dengan Putusan Nomor 1010/K/PDT/2014, tanggal 26 Agustus 2015

- Bahwa kemudian Tergugat PT: Hijau Pryan Perdana (HPP) mengajukan Peninjauan Kembali 
(PK) yang hasilnya adalah mengabulkan permohonan Peninjauan Kembali (PK) dari Tergugat PT. Hijau Pryan Perdana (HPP) dan membatalkan seluruh putusan Pengadilan Negeri Rantau Prapat, Pengadilan Tinggi Medan dan Kasasi Mahkamah Agung sesuai dengan Putusan Nomor 135/PK/PDT/2016, tanggal 18 Jul 2016; Bahwa setelah adanya Putusan Peninjauan Kembali (PK) tersebut ternyata di dalam Putusan itu dicantumkan sebagai alas hak dari Penggugat yang digunakan Terdakwa untuk persidangan perdata yaitu ketiga buah Surat Penyerahan Ganti Kerugian yang ada materainya palsu;

- Bahwa didalam ketiga Surat Penyerahan Ganti Kerugian tertanggal 15 Februari 2000 yang ada meterainya tersebut ternyata meterainya saat itu belum berlaku dan saksi tidak mengetahui siapa membuat surat tersebut;

- Bahwa Terdakwa tidak pernah menguasai dan mengusahai tanah tersebut karena PT. Hijau Pryan Perdana (HPP) dari dulu sampai sekarang menguasai dan mengusahai dengan cara

menanam kelapa sawit;

- Bahwa kerugian yang dialami oleh PT. Hijau Pryan Perdana (HPP) akibat Terdakwa tersebut adalah sebesar Rp. 1.260.000.000 (Satu milyar dua ratus enam puluh juta rupiah) karena produksi sawit diatas lahan seluas 30 (Tiga puluh) Ha dimaksud menjadi menurun selama 7 (tujuh) tahun terhitung sejak tahun 2011 sampai dengan 2017 karena selama 7 (tujuh) tahun tanah tersebut berperkara di Pengadilan;

Terhadap keterangan saksi tersebut. Terdakwa menyatakan tidak keberatan;

4. Saksi AGB dan $S$ menerangkan sebagai berikut :

- Bahwa saksi bekerja di PT. Hijau Pryan Perdana (HPP) menjabat sebagai Regional Manager:

- Ini Bahwa PT. Hijau Pryan Perdana (HPP) ada mempunyai sebidang tanah di Desa Telaga Suka Kecamatan Panai Tengah Kabupaten Labuhanbatu kemudian Terdakwa mengklaim dia sebagai pemilik tanah yang dikuasai oleh PT. Hijau Pryan Perdana (HPP) tersebut lalu Terdakwa mengajukan gugatan perdata di Pengadilan Negeri 
Rantauprapat yang mana

Terdakwa selaku Penggugat dan

PT. Hijau Pryan Perdana (HPP)

sebagai Tergugat:

- Bahwa ada pun hasil putusan gugatan perdata pada tingkat di Pengadilan Negeri Rantau Prapat adalah menerima dan mengabulkan gugatan Penggugat sesuai dengan Putusan Nomor 25/Pdt.G/2011/PN RAP tanggal 2 Agustus 2012 lalu Banding di Pengadilan Tinggi Medan adalah menguatkan Putusan Pengadilan Negeri Rantau Prapat sesuai dengan Putusan Nomor 120/PDT/2013/PT MDN tanggal 27 Juni 2013 dan pada tingkat kasasi Mahkamah Agung adalah menolak Kasasi sesuai dengan Putusan Nomor

1010/K/PDT/2014, tanggal 26 Agustus 2015:

- Bahwa kemudian Tergugat PT. Hijau Pryan Perdana (HPP)mengajukan Peninjauan Kembali (PK) yang hasilnya adalah mengabulkan permohonan Peninjauan Kembali (PK) dari Tergugat PT. Hijau Pryan Perdana (HPP) dan membatalkan seluruh putusan Pengadilan Negeri Rantau Prapat, Pengadilan Tinggi Medan dan Kasasi Mahkamah Agung sesuai dengan Putusan Nomor 135/PK/PDT/2016, tanggal 18

Juli 2016; Bahwa setelah adanya Putusan Peninjauan Kembali (PK) tersebut ternyata didalam Putusan itu dicantumkan sebagian alas hak dari Penggugat yang digunakan Terdakwa untuk persidangan perdata yaitu ketiga buah Surat Penyerahan Ganti Kerugian yang ada meterainya diduga palsu Bahwa didalam ketiga Surat Penyerahan Ganti Kerugian tertanggal 15 Februari 2000 yang ada meterainya tersebut ternyata meterainya saat itu belum berlaku dan saksi tidak mengetahui siapa yang membuat surattersebut; Bahwa Terdakwa tidak pernah menguasai dan mengusahai tanah tersebut karena PT. Hijau Pryan Perdana (HPP) dari dulu sampai sekarang menguasai dan menguasai dengan cara menanam kelapa sawit:

- Bahwa kerugian yang dialami oleh PT. Hijau Pryan Perdana (HPP) akibat Terdakwa tersebut adalah sebesar Rp. 1.260.000.000 Satu milyar dua ratus enam puluh juta rupiah) karena produksi sawit diatas lahan seluas 30 (Tiga puluh) Ha dimaksud menjadi menurun 
selama 7 (tujuh) tahun terhitung sejak tahun 2011 sampai dengan 2017 karena selama 7 (tujuh) tahun tanah tersebut berperkara di Pengadilan:

Terhadap keterangan saksi tersebut, terdakwa menyatakan tidak keberatan

\subsection{Hal-hal yang memberatkan:}

- Perbuatan Terdakwa telah merugikan PT. Hijau Pryan Perdana (HPP)

- Perbuatan Terdakwa dapat meresahkan masyarakat;

\subsection{Hal-hal yang meringankan:}

- Terdakwa tidak berbeli-belit dalam memberikan keterangan sehingga memperlancar proses belum prnah dihukum;

- Terdakwa belum pernah di hukum;

\subsection{Putusan}

(1) Menyatakan Terdakwa Irham Alias Irham Nasution tersebut diatas tidak terbukti secara sah dan meyakinkan bersalah melakukan tindak pidana sebagaimana dalam Dakwaan Primair, Subsidair Serta Lebih Subsidair,

(2) Membebaskan Terdakwa dari Dakwaan Primair. Subsidair Serta Lebih Subsider:

(3) Menyatakan Terdakwa Ilham Alias Irham Nasution tersebut diatas terbukti secara sah dan meyakinkan bersalah melakukan tindak pidana "Mempergunakan Surat Palsu" sebagaimana dalam Dakwaan Lebih Subsidair lagi

(4) Menjatuhkan pidana kepada Terdakwa oleh karena itu dengan pidana penjara selama 1 (satu) tahun, 6 (enam) bulan,

(5) Menetapkan masa penangkapan dan penahanan yang telah dijalaniTerdakwa dikurangkan seluruhnya dari pidana yang dijatuhkan

(6) Menetapkan Terdakwa tetap ditahan

(7) Menetapkan barang bukti berupa:

- 1 rangkap photocopy legalisir

- Putusan Mahkamah Agung Republik Indonesia No. 135 PK/PDT/2016 Tanggal 18 Juli 2016: - rangkap photocopy legalisir Putusan Mahkamah Agung RepublikIndonesia No. 1010 PK/PDT 2014 Tanggal 26 Agustus 2014

- 1 rangkap photocopy legalisir Putusan Pengadilan Tinggi Sumatera Utara di Medan No. $120 \quad \mathrm{PDT} / 2013 / \mathrm{PT} \quad \mathrm{MDN}$ Tanggal 27 Juni 2013

- 1 rangkap fotocopy legalisir Putusan Pengadilan Negeri Rantauprapat No. 25/Pdt.G/2011/PN RAP Tanggal 02 Agustus 2012 
- 1 rangkap fotocopy legalisir

berita acara pembayaran ganti

rugi atas penyerahan dan

pelepasan hak atas tanah garapan

Desa Telaga SukaKec. Panai

Tengah tanggal 05 Desember

2006; 1 rangkap fotocopy

legalisir perjanjian pembayaran

ganti rugi atas penyerahan dan

pelepasan hak atas tanah garapan

Desa Telaga Suka Kec.Panai

Tengah tanggal 05 Desember

2006:

- 1 rangkap fotocopy legalisir berita acara pembayaran ganti rugi atas penyerahan dan pelepasan hak atas tanah garapan Desa Telaga Suka Kec. Panai Tengah tanggal 19 Juni 2019,

- 1 rangkap fotocopy legalisir perjanjian pembayaran ganti rugi atas penyerahan dan pelepasan hak atas tanah garapan Desa Telaga Suka Kec. Panai Tengah tanggal 19 Juni 2019: Tetap tertampil dalam berkas perkara:

- Surat Penyerahan Ganti Kerugian atas tanah seluas 100.000 $\mathrm{M}^{2}$ (10 Hektar), yang terletak di Desa Telaga Suka Kec. Panai Tengah Kab.Labuhanbatu dari pihak pertama bernama H Nega Hasibuan kepada pihak kedua atas nama irham Nasution yang dikeluarkan pada tanggal 15 Februari 2000 bermaterai 6.000 (enam ribu) yang turut diketahui oleh Kepala Desa Telaga Suka Atas nama Solehuddin Nasution Surat Penyerahan Ganti Kerugian atas tanah seluas $100.000 \mathrm{M}^{2}$ (10 Hektar) yang teracak di Desa Telaga Suka Kec Panai tengah Kab Labuhan batu dari pihak pertama bernama H. Baital Ritonga kepada pihak kedua atas nama Irham Nasution yang dikeluarkan pada tanggal 15 Pebruari 2000 bermeterai 6.000 (enam ribu) yang turut diketahui oleh Kepala Desa Telaga Suka Atas nama Solehuddin Nasution Surat Penyerahan Ganti Kerugian atas tanah seluas 100.000 M2 (10 Hektar), yang terletak di Desa Telaga Suka Kec. Panai Tengah Kab. Labuhanbatu dari pihak pertama bernama Mukhyar kepada pihak kedua atas nama Irham Nasution yang 
dikeluarkan pada tanggal

15 Pebruari 2000

bermeterai 6.000 (enam

bu) yang turut diketahui

oleh Kepala Desa Telaga

Suka An. Solehuddin

Nasution; Dimusnahkan

- Membebankan kepada

Terdakwa membayar biaya perkara sejumlah $\mathrm{Rp}$

5.000,00 (lima ribu

rupiah);

\section{KESIMPULAN}

Berdasarkan hasil penelitian dan pembahasan diatas, maka penulis menarik kesimpulan sebagai berikut: Terdakwa didakwa dengan dakwaan alternatif yaitu pertama Pasal 263 ayat (2) KUHPidana dan Undang-undang Nomor 8 Tahun 1981 Tentang Hukum Acara Pidana serta Peraturan Perundang-undangan lain yang bersangkutan. Terdakwa tersebut diatas terbukti secara sah dan meyakinkan bersalah melakukan tindak pidana "mempergunakan surat palsu" sebagaimana dalam dakwaan lebih subsidair lagi; tetapi terdakwa tidak terbukti secara sah dan meyakinkan bersalah melakukan tindak pidana sebagaimana dalam dakwaan primair, subsidair serta lebih subsidair. Petimbangan Hukum Majelis Hakim dalam penjatuhan putusan selain berdasar pada alat bukti yang sah yang terungkap di persidangan dan juga terpenuhinya unsur dari dakwaan kesatu penuntut umum yaitu menurut pasal 263 ayat
(1) KUHP mengenai membuat surat palsu, terdakwa juga membayar ganti kerugian.

\section{Buku - buku :}

\section{DAFTRAR PUSTAKA}

Adami Chazawi I Ardi Ferdian, 2014, Tindak Pidana Pemalsuan, PT Raja Grafindo Persada,

Adami Chazawi, Kejahatan Terhadap Tubuh \& Nyawa, Rajawali Pers, Jakarta, 2001

Adami Chazawi. Kejahatan Terhadap Pemalsuan. PT. Raja Grafindo Persada. Jakarta.2001

Adami Chazawi. Pelajaran Hukum Pidana 1.PT. RajaGrafindo Persada. Jakarta.2001.

Adami Chazawi. PelajaranHukumPidana1. PT. RajaGrafindoPersada.2005

Amir Ilyas. Asas-Asas Hukum Pidana. Rangkang Education dan PuKap. Yoyakarta. 2012.

Andi Hamzah, Hukum Acara Pidana Indonesia, Sinar Grafika, Jakarta.2008

Andi Zainal Abidin Farid.AsasAsasHukumPidana 1. Alumni. Bandung.1987.

Andi Zainal Abidin Farid. HukumPidana I. Cetakan Kedua. Sinar Grafika. Jakarta.2007

Rusli. 1978. Asas-Asas Hukum Pidana. LEPPEN-UMI, Ujung Pandang

Hamzah, Andi. Asas-Asas Hukum Pidana. Jakarta. Rineka Cipta.2008.

Ilham Gunawan. Kamus Hukum. CV. Restu Agung. Jakarta. 2002.

Ismu Gunadi dan Jonaedi Efendi, Cepat dan Mudah Memahami Hukum Pidana, Jakarta, Kencana Prenadamedia Group, 2014

Jannah, M. (2017). Penerapan Sanksi Pidana Terhadap Pelaku Kekerasan Dalam Rumah Tangga Dalam Perspektif Undang-Undang Nomor 23 Tahun 2004 Tentang Penghapusan Kekerasan Dalam Rumah Tangga (Studi Putusan No. 616 / PID.B / 2010 / PNRAP). Jurnal Ilmiah Advokasi, 5 (2), 42 - 
65.

doi:https://doi.org/10.36987/jiad.v5i2.3 $\underline{05}$

Lamintang dan Theo Lamintang, Hukum Penitensier Indonesia; Edisi Kedua, Sinar Grafika, Jakarta, 2010.

Lamintang, P.A.F. dan Lamintang Theo, 2009, Delik-Delik Khusus Kejahatan Membahayakan Kepercayaan Umum Terhadap Surat, Alat Pembayaran, Alat Bukti, Dan Peradilan, Sinar Grafika, Jakarta.

Leden Marpaung, 2014, Asas Teori Praktik Hukum Pidana, Jakarta.

Marwan dan Jimmy P. "Kamus Hukum: Dictionary Of Law Complete Edition", Reality Publisher, Surabaya. 2009.

Moeljatno, Asas-asas Hukum Pidana, Rineka Cipta, Jakarta, 2009 Asas-Asas Hukum Pidana. Rineka Cipta, Jakarta, 2008.

Muhammad Ekaputra dan Abdul Kahir. Sistem Pidana di Dalam KUHP dan Pengaturannya Menurut Konsep KUHP Baru. Medan: Usu Press.2010.

P.A.F. Lamintang, Delik-Delik Khusus Kejahatan Terhadap Nyawa, Tubuh dan Kesehatan, Sinar Grafika, Jakarta, 2012

R. Soesilo, 1991, Kitab Undang-Undang Hukum Pidana (KUHP) serta Komentar-Komentarnya Lengkap Pasal Demi Pasal, Poleia, Bogor.

Soerjono Soekanto, Sri Mamudji, 1995

Penelitian Hukum Normatif: Suatu

Tinjauan Singkat, Cet.4, Jakarta: Rajawali Press

Soerodibroto, Soenarto. Kitab UndangUndang Hukum Pidana dan Kitab Undang-Undang Hukum Acara Pidana. Jakarta: Raja Grafindo. 1994.

Subekti. Kamus Hukum. PT. Pradnya Paramita. Jakarta.2005.

Sudarto. Hukum Pidana 1, Semarang: Yayasan Soedarto d/a Fakultas Hukum Universitas Diponegoro. 1990.

Topo Santoso, Kriminologi. PT. Raja GrafindoPersada.

Jakarta.2001.Effendy,
Marpaung, Marudut. Pengaruh Kepemimpinan dan Team Work terhadap Kinerja Karyawan di Koperasi Sekjen Kemdikbud Senayan Jakarta. Jurnal Ilmiah Widya Vol.2, No.1. Jakarta: STIE Dharma Bumiputra Jakarta. 2014.

\section{Peraturan Perundang-undangan :}

KitabUndang-UndangHukumPidana (KUHP), 2010.CetakanKedua. PT. Buku Kita. Jakarta Kitab Undang-Undang Hukum Acara Pidana

Undang-Undang Nomor 4 Tahun 2004 tentang Kekuasaan Kehakiman

Undang - Undang Dasar Negara Kesatuan Republik Indonesia tahun 1945

Undang - Undang Nomor 1 tahun 1946 (Kitab Undang - Undang Hukum Pidana)

Undang - Undang Nomor 8 tahun 1981 tentang Hukum Acara Pidana

\section{Jurnal}

